\title{
The role of fluorine in the concentration and transport of lithophile trace elements in felsic magmas: Insights from the Gawler Range Volcanics, South Australia
}

\author{
Andrea Agangi *, Vadim S. Kamenetsky, Jocelyn McPhie \\ ARC Centre of Excellence in Ore Deposits and School of Earth Sciences, University of Tasmania, Private bag 79, Hobart, Tasmania, Australia
}

\section{A R T I C L E I N F O}

Article history:

Received 2 September 2009

Received in revised form 16 March 2010

Accepted 17 March 2010

Editor: D.B. Dingwell

\section{Keywords:}

Fluorine

Rare earth elements (REE)

High field strength elements (HFSE)

Late-stage magmatic fluid

\begin{abstract}
A B S T R A C T
Rhyolites of the Mesoproterozoic Gawler Range Volcanics (GRV) of South Australia are characterised by high concentrations of some trace elements (REE, Y, HFSE, Rb and F, in particular). Whole rock geochemical data suggest that these elements were incompatible during magma crystallisation. Accessory minerals (fluorite, zircon, REE-F-carbonate, Ti oxide, apatite, and titanite) can account for most of the trace element content of the rocks. These minerals occur in vesicles, micromiaroles, lithophysal vugs and in interstices between major mineral phases (quartz and feldspar as both phenocrysts and groundmass). Such textural evidence indicates that accessory minerals crystallised late in the history of the magma and that they were deposited from a volatile-rich (fluid) phase. These features are explained by the following sequence of events: 1) F dissolved in the magma lowered the crystallisation temperature of accessory minerals, causing trace elements (REE, Y, and HFSE) to behave as incompatible elements. 2) Protracted crystallisation of major mineral phases (quartz, feldspar, and oxides) formed a volatile- and trace element-enriched residual liquid. 3) A volatile element $\left(\mathrm{H}_{2} \mathrm{O}, \mathrm{F}\right.$, and $\left.\mathrm{CO}_{2}\right)$-rich phase (late-stage magmatic fluid) evolved from the magma. High concentration of fluorine and other complexing agents in this phase allowed trace elements to be transported in solution. 4) Accessory minerals crystallised from such a phase in vesicles, micromiaroles and interstices between the major mineral phases.
\end{abstract}

(C) 2010 Elsevier B.V. All rights reserved.

\section{Introduction}

Fluorine (F) plays an important role in several processes occurring in magmas and associated fluids. Experimental studies indicate that $\mathrm{F}$ dissolved in silicate liquids strongly influences phase equilibria by decreasing solidus temperature and shifting the eutectic composition away from quartz in the granitic ternary diagram (Manning, 1981). Fluorine reduces viscosity and increases ion diffusivity in silicate melts (Dingwell et al., 1985; Giordano et al., 2004). Fluorine has also been shown to have a major influence on the activity coefficients of trace elements in magmas by increasing the solubility of zirconium and other high field strength elements (HFSE) (Keppler, 1993). The capacity of halogens ( $\mathrm{F}$ and $\mathrm{Cl}$ ) to bond with and to transport lithophile elements (e.g. REE, Nb, Th, U, Ba), commonly considered as immobile in an aqueous fluid (e.g. Cullers et al., 1973; Lesher et al., 1986; Michard and Albarède, 1986; Möller et al., 2003), has been confirmed by experimental data (London et al., 1988; Webster et al., 1989; Keppler and Wyllie, 1990; 1991). Evidence indicating the association of these elements and F-bearing mineralising fluids has been reported by several authors in different natural systems, including felsic magmatic systems (Gieré, 1986;

\footnotetext{
* Corresponding author. Tel.: +61 36226 2391; fax: +61362267662. E-mail address: aagangi@utas.edu.au (A. Agangi).
}

Charoy and Raimbault, 1994; Audétat et al., 2000; Webster et al., 2004; Schönenberger et al., 2008), metamorphic rocks (Gieré and Williams, 1992; Pan and Fleet, 1996; Rubatto and Hermann, 2003). This paper reports the presence of late-formed aggregates of F-, REE (lanthanides, U, and Th)-, Y- and HFSE (Ti, Zr, and Nb)-rich minerals filling vesicles, micromiarolitic cavities and lithophysal vugs in rhyolitic units of the Gawler Range Volcanics of South Australia. These minerals indicate mobility of such elements in the late magmatic stage. We also discuss (1) the characteristics of the phase (here referred to as late-stage magmatic fluid) that transported these elements, as inferred from mineralogical and textural data, (2) the role of complexing agents in the transport of REE and HFSE and (3) the capacity for F-rich magmas to produce distinctive trace element-rich late-stage magmatic fluids.

\section{Vesicles, micromiarolitic cavities and lithophysal vugs}

Despite textural differences, vesicles, micromiarolitic cavities and lithophysal vugs share a common origin as a consequence of magmatic volatile element concentration and imply the presence of a volatile-rich, alumino-silicate-poor fluid phase (Roedder, 1981; London, 1986). This phase can be permanently entrapped on solidification and crystallise in situ, and evidence of its characteristics can be preserved by minerals precipitating in these cavities. 
Vesicles form in lavas, shallow intrusions and densely welded pyroclastic facies as a result of exsolution of a volatile phase (McPhie et al., 1993). Miarolitic cavities (miaroles) can be found in shallow intrusions and comprise crystals of magmatic, super-solidus minerals projecting into either a cavity or a mass of hydrothermal minerals (London, 1986; Candela, 1997; Kile and Eberl, 1999). Such "external" nucleation of super-solidus minerals (nucleation on the former fluid phase interface) determines the irregular shape of these cavities (Candela and Blevin, 1995; Candela, 1997). Lithophysae consist of radially oriented crystallites, sometimes concentrically chambered, distributed around a circular to star shaped vug (McArthur et al., 1998). They occur in lavas and welded pyroclastic deposits and can reach a few tens of centimetres in diameter. The central vug forms during crystallisation and it may remain open or be lined or filled with minerals (McPhie et al., 1993). Although the origin is debated, ductile or ductile-brittle deformation of lithophysae provides evidence for high-temperature crystallisation within the melt (Cas and Wright, 1987; McArthur et al., 1998 and ref. therein).

\section{Geological setting and sample description}

\subsection{Geological setting}

The Gawler Range Volcanics (GRV) and co-magmatic Hiltaba Suite (HS) Granite represent a silicic large igneous province with an outcrop extent of more than $25000 \mathrm{~km}^{2}$ and a total estimated magma volume of $100000 \mathrm{~km}^{3}$ (Blissett et al., 1993; Fig. 1). The volcano-plutonic province was emplaced in an intracontinental setting in the Mesoproterozoic, during the Laurentian supercontinent assembly (Blissett et al., 1993; Allen and McPhie, 2002; Allen et al., 2008). U-Pb zircon dating of the GRV has yielded ages of 1591-1592 Ma (Fanning et al., 1988). The HS granite has ages that span a time interval between $1583 \pm 7$ and $1598 \pm 2 \mathrm{Ma}$ (U-Pb zircon dates; Flint, 1993). The giant $\mathrm{Cu}-\mathrm{Au}-\mathrm{U} \pm \mathrm{Ag}$ Olympic Dam deposit is hosted in the GRV-HS province. The deposit is enriched in REE and $\mathrm{F}$ compared to crustal values (Bailey, 1977; Hu and Gao, 2008). The units in the GRV range in composition from basalt to rhyolite and mainly comprise lavas and

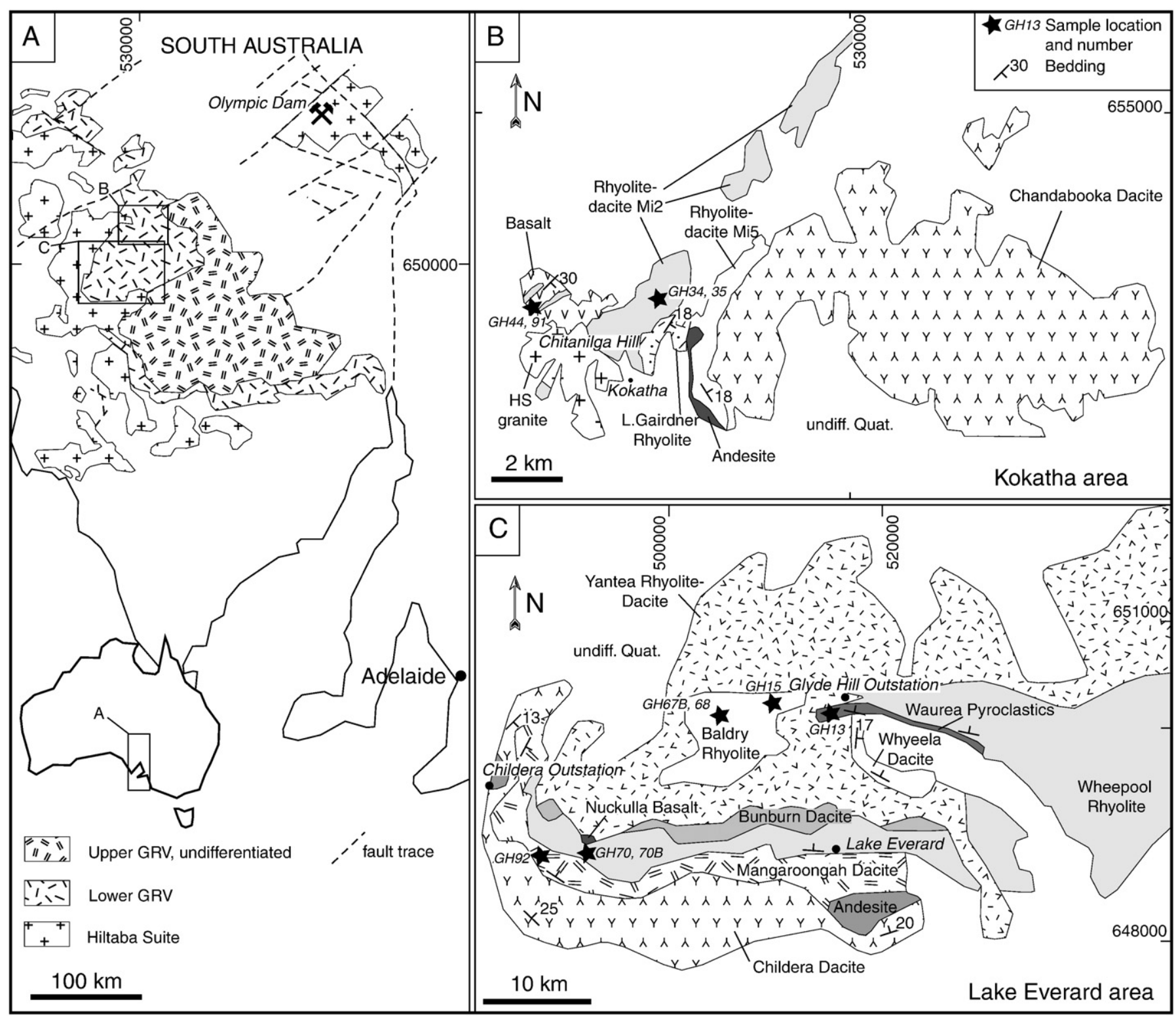

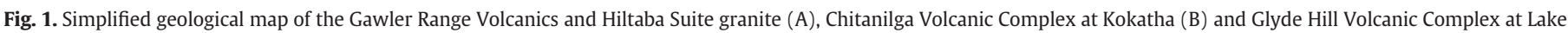
Everard (C). After Blissett (1975, 1993). Grid: GDA94. 
ignimbrites. The GRV are essentially undeformed and unmetamorphosed and primary textures are well preserved. The GRV have been subdivided into lower and upper sequences (LGRV and UGRV, Blissett et al., 1993). The Chitanilga Volcanic Complex at Kokatha and Glyde Hill Volcanic Complex at Lake Everard are the two best exposed parts of the lower GRV (Fig. 1) and are the objects of the present study. The Chitanilga Volcanic Complex is $3 \mathrm{~km}$ thick and includes basalt (at the base of the sequence), minor andesite and rhyolite (Blissett, 1975; Branch, 1978). The Glyde Hill Volcanic Complex is a $1 \mathrm{~km}$ thick sequence. Felsic units (porphyritic lavas and volcaniclastic facies) dominate over andesite and basalt (Blissett, 1975; Giles, 1977). Several units have been intruded by felsic porphyritic dykes.

\subsection{Sample description}

Four units locally containing either vesicles, micromiaroles or lithophysae were examined in thin sections and rock slabs for this study (Table 1, Fig. 2). These include both volcanic and subvolcanic rocks, all rhyolitic in composition. The samples are generally fresh, despite a minor to moderate sericitisation of feldspar. Whole rock chemical analyses indicate decreasing $\mathrm{CaO}, \mathrm{MgO}, \mathrm{P}_{2} \mathrm{O}_{5}$ and $\mathrm{Sr}$ and increasing $\mathrm{K}_{2} \mathrm{O}$, REE, HFSE ( $\mathrm{Zr}, \mathrm{Nb}, \mathrm{Rb}$, and $\mathrm{Ga}$ ) and $\mathrm{Y}$ with increasing silica (Fig. 3, Table 2). Some of these elements show continuously increasing trends ( $\mathrm{Nb}$, and $\mathrm{Th}$ ), whereas other elements increase with silica up to about $70 \mathrm{wt} . \%$ and decrease in the most evolved compositions ( $\mathrm{Zr}$ and, to a lesser extent, Ce, Fig. 3). The generally positive evolution trends of most lithophile trace elements indicate incompatible behaviour, leading to high concentrations of HFSE and REE in felsic compositions (e.g. Ce $\leq 200$ ppm, $\mathrm{Zr} \leq 650-700$ ppm and $\mathrm{Th} \leq 40 \mathrm{ppm}$ at $\mathrm{SiO}_{2}=70$ wt.\%).

\section{Analytical techniques}

Selected samples were crushed in a tungsten carbide mill for X-ray fluorescence (XRF) and inductively coupled plasma mass spectrometry (ICP-MS) whole rock analysis at the University of Tasmania. Samples were digested in $\mathrm{HF} / \mathrm{H}_{2} \mathrm{SO}_{4}$ with the PicoTrace high pressure digestion equipment and analysed with a Philips PW1480 X-ray Fluorescence Spectrometer and an Agilent 4500 ICP-MS. Detection limits for trace elements in ICP-MS are $\leq 0.01 \mathrm{ppm}$ (REE) and $\leq 0.5 \mathrm{ppm}$ for other elements, except As (5 ppm). A comparison of XRF and ICP-MS trace element data indicates a good correlation between the two methods, the difference being $<20 \%$.

Laser ablation ICP-MS traverses were carried out in order to compare the distribution of REE ( $\mathrm{La}-\mathrm{Lu}$ ), Y, Th, Nb, Pb, U, Cu, Zn, Mo, Cs, Rb, Ba, W, $\mathrm{Si}, \mathrm{Al}, \mathrm{Ti}, \mathrm{Fe}, \mathrm{Ca}$ and $\mathrm{P}$ in vesicles and in the surrounding groundmass from the Rhyolite-dacite (sample GH35). A New Wave UP-213 Laser and an Agilent 4500 ICP-MS mass spectrometer were used. The laser was operated at a frequency of $10 \mathrm{~Hz}$ and at $3.6-3.7 \mathrm{~J} / \mathrm{cm}^{2}$. A large spot size $(100 \mu \mathrm{m})$ in comparison with the average grain size in the groundmass $(\sim 10 \mu \mathrm{m})$ was used in order to obtain "average" multi-grain values. Glass NIST 612 was used as the primary standard. The results of laser ablation traverses are used in two ways: (1) To map the distribution of trace elements and to identify trace element-bearing mineral phases by comparing concurrent peaks (qualitative use). It is possible, for instance, to identify a titanite grain by locating concurrent Ti and Ca peaks and to assess its contribution to the trace element signal. (2) To quantify the trace element contents of the groundmass and vesicles.

Electron microprobe (EPMA) compositional maps were produced to show the distribution of major elements around vesicles in the Rhyolite-dacite. Maps were obtained using a five spectrometerequipped Cameca X100 microprobe. A 15 KV accelerating voltage and a spatial resolution of $3 \mu \mathrm{m}$ were used. Measured elements include $\mathrm{Si}$, Ti, Al, Fe, Ca, K, Na and La.

Cathodoluminescence (CL) images were obtained on polished carbon-coated samples with a FEI Quanta 600 scanning electron microscope (SEM) operated at $10 \mathrm{kV}$ and equipped with a Gatan PanaCLF CL detector.

\section{Mineral assemblages in vesicles, micromiaroles and lithophysae}

\subsection{Vesicle-filling assemblage}

Elongate and aligned vesicles, $<5$ vol.\% of the sample (GH35), are lined with quartz and filled with epidote (pistacite), Y-bearing fluorite, fibrous Mn-bearing chlorite, \pm titanite, \pm REE-fluoro-carbonate (synchysite-(Ce)?, $\left.\mathrm{Ca}(\mathrm{Ce}, \mathrm{La}) \mathrm{F}\left(\mathrm{CO}_{3}\right)_{2}\right)$, \pm baryte (Fig. 4A, B). Cathodoluminescence images allow distinction of euhedral quartz from fan-shaped aggregates of needle-like silica crystals, both growing inwards from the walls (Fig. 4C). Although the vesicles are elongate, crystals within the vesicles show no preferential orientation implying a static growth. The groundmass of the rock is very fine grained $(\leq 10 \mu \mathrm{m})$ and displays concentric zones of minerals around the vesicles (Fig. 4D).

Table 1

Textural and compositional characteristics of the GRV rhyolite samples.

\begin{tabular}{|c|c|c|c|c|}
\hline Unit & Rhyolite-dacite (Mi2) & Baldry Rhyolite & Moonamby Dyke Suite & Microgranite Dykes \\
\hline Locality & Kokatha & Lake Everard & Lake Everard & Kokatha \\
\hline Samples & GH34, GH35* & GH67, GH68* & GH15*, GH70, GH70B, GH92 & GH44*, GH91* \\
\hline Emplacement & Lava & Lava & Shallow intrusion & Shallow intrusion \\
\hline Texture & Porphyritic \pm vesicular & Porphyritic \pm lithophysal & Porphyritic \pm micromiarole-bearing & Seriate-equigranular \\
\hline $\begin{array}{l}\text { Phenocryst } \\
\text { grainsize }\end{array}$ & $\leq 1-2 \mathrm{~mm}$ & $\leq 2 \mathrm{~mm}$ & $\leq 3 \mathrm{~cm}$ & $\leq 2 \mathrm{~mm}$ \\
\hline Phenocryst & Albite & K-feldspar, quartz & Quartz, albite, K-feldspar & Quartz, albite, K-feldspar (perthite), biotite \\
\hline Groundmass & Quartz, albite, K-feldspar & Quartz, albite, K-feldspar & Quartz, albite, K-feldspar & \\
\hline $\begin{array}{l}\text { Accessory } \\
\text { minerals }\end{array}$ & $\begin{array}{l}\text { Fe oxide, Ti oxide, fluorite, } \\
\text { apatite, REE-F-carbonate, } \\
\pm \text { monazite }\end{array}$ & $\begin{array}{l}\text { Fe oxide, Ti oxide, fluorite, } \\
\text { zircon }\end{array}$ & $\begin{array}{l}\text { Fe oxide, Ti oxide, fluorite, apatite, REE-F- } \\
\text { carbonate }\end{array}$ & $\begin{array}{l}\text { (Y-)fluorite, Nb-Ti oxide, REE-F-carbonate, Fe oxide, } \\
\pm \text { epidote, } \pm \text { allanite, } \pm \text { biotite, } \pm \text { muscovite, } \pm \text { zircon, } \\
\pm \text { apatite, } \pm \text { monazite, } \pm \text { topaz }\end{array}$ \\
\hline $\begin{array}{l}\text { Groundmass } \\
\text { texture }\end{array}$ & $\begin{array}{l}\text { Microcrystalline }(< \\
20 \mu \mathrm{m})\end{array}$ & $\begin{array}{l}\text { Microcrystalline ( } \leq 20 \mu \mathrm{m}) \text {, } \\
\text { "herring bone-like" quartz } \\
\text { and K-feldspar }\end{array}$ & $\begin{array}{l}\text { Microcrystalline }(\leq 100 \mu \mathrm{m}) \text {, poikilitic } \\
\text { quartz, radially oriented } \mathrm{K} \text {-feldspar } \\
\text { around quartz phenocrysts }\end{array}$ & Quartz-K-feldspar granophyric texture \\
\hline $\begin{array}{l}\text { Phenocryst } \\
\text { modal } \\
\text { abundance }\end{array}$ & $\leq 10 \%$ & $<1 \%$ & $10-20 \%$ & - \\
\hline $\begin{array}{l}\text { Chemical } \\
\text { classification } \\
\text { (Le Bas et al., } \\
\text { 1986) }\end{array}$ & Rhyolite-dacite & Rhyolite & Rhyolite & Rhyolite \\
\hline
\end{tabular}

*Vesicle-/micromiarole-/lithophysa-bearing sample. 

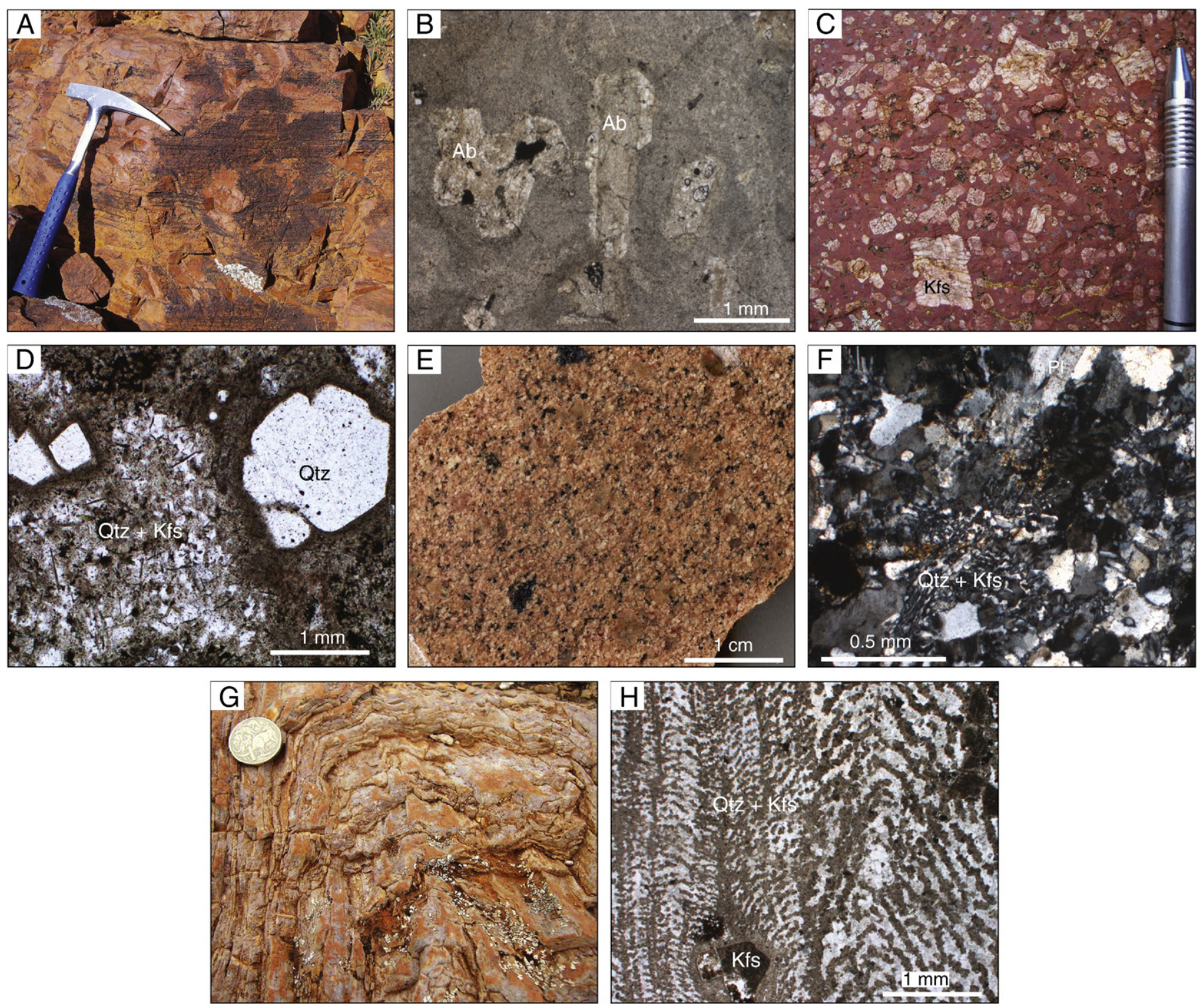

Fig. 2. A, B. Rhyolite-dacite Mi2. A. mm-scale flow bands; B. sericite-altered albite phenocrysts in a microcrystalline groundmass (sample GH34, transmitted plane polarised light). C., D. Moonamby Dyke Suite. C. Centimetre-scale phenocrysts of K-feldspar and quartz and (D) phenocrysts of quartz in a micropoikilitic quartzo-feldspathic groundmass (sample GH15, transmitted plane polarised light). E, F. Microgranite dyke. E. specimen and (F) seriate texture with K-feldspar, albitic plagioclase and quartz (sample GH44, transmitted light, crossed nichols). G, H. Baldry Rhyolite. G. Flow-folded flow bands and (F) phenocryst of K-feldspar and a $\mu \mathrm{m}$-scale quartz and K-feldspar layers in the groundmass (sample GH67B, transmitted plane polarised light). Abbreviations: Ab: albite, Kfs: K-feldspar, Pl: plagioclase, Qtz: quartz.

\subsection{Micromiaroles}

Irregular-shaped aggregates with jagged margins form approximately 5 vol.\% of the sample (GH15) and include Y-bearing fluorite, Nb-bearing Ti oxide (identified as anatase for its optically negative character), zircon, REE-F-carbonate (synchysite-(Ce)?), F-apatite, quartz and chlorite-altered biotite (Fig. 5A, B). Titanium oxide and apatite form euhedral prismatic crystals growing towards the centre of the cavity. These aggregates, $\leq 1 \mathrm{~mm}$ in size, have sharp borders without any alteration halo and are not interconnected by or related to fractures.

\subsection{Interstitial accessory assemblage}

The Microgranite dykes (samples GH44 and GH91) show a complex accessory mineral assemblage including fluorite, a Th-bearing REEfluoro-carbonate, Nb-bearing Ti oxide, Fe oxide, chlorite-altered biotite, \pm epidote, \pm allanite, \pm zircon, \pm muscovite, \pm topaz, \pm monazite and \pm titanite. All the accessory minerals occur in interstitial positions between the major phases (Fig. 5C, D), with the exception of zircon, topaz and monazite. In these samples, zircon occurs as inclusions in quartz. For topaz and monazite, textural relationships are obscured by sericite localised around the margin and along fractures, and by a pleochroic (radiation damage) halo in the surrounding minerals, respectively.

\subsection{Lithophysae}

Lithophysal vugs (sample GH68) are partly filled with quartz, thinly layered amorphous silica, Y-bearing fluorite and minor amounts of $\mathrm{Ca}-$ $\mathrm{Mg}$ carbonate, Fe oxide and baryte. The minerals are roughly concentrically arranged: quartz is directly deposited in contact with the walls and fluorite deposited in a later stage in the internal portions of the vug (Fig. 6). Three types of silica can be distinguished by combining CL and back scattered electron (BSE) images (type I- highly CL-contrasted euhedral quartz, type II- $\mu \mathrm{m}$-scale layered silica blanketing type I silica, 

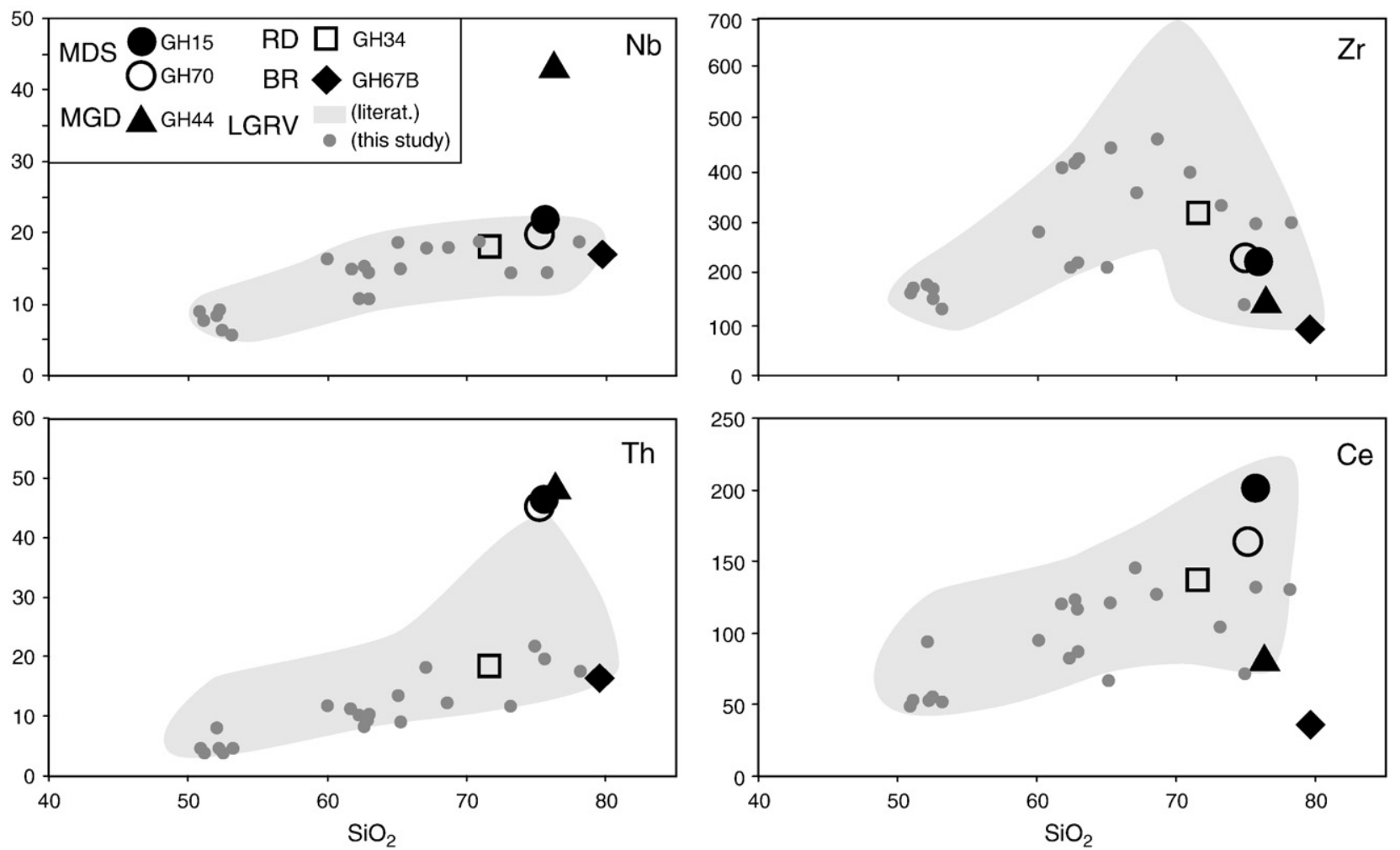

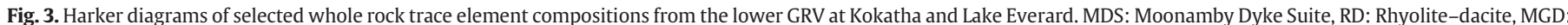
Microgranite Dyke, BR: Baldry Rhyolite. LGRV literature data from Giles (1988).

type III-elongate prismatic crystals showing patchy CL) (Fig. 6B). Type III silica is present within the CL-banded quartz (type I) and between the latter and the vug walls. Fine grained Fe oxide and Sr-bearing baryte aggregates occur along the contact between the first and second types of silica. Fluorite overgrew layered silica, as shown by truncation relationships.

\section{Chemical composition and systematics of vesicles and surrounding groundmass}

Zones in the groundmass around vesicles were studied with a combination of optical microscopy, BSE images and compositional maps. Starting from an inner position (next to the vesicle walls), the concentric zones are (Figs. 7B, cf. 4D):

1) 0 -150- $\mu \mathrm{m}$-thick zone enriched in K-feldspar \pm Fe oxide \pm Ti oxide, quartz \pm titanite;

2) 100 - $\mu$ m-thick, quartz, albite, K-feldspar (feldspars <20-30\%) zone;

3) 200-300- $\mu$ m-thick, albite-rich zone;

4) outer zone relatively rich in quartz, K-feldspar, Fe oxide and $\mathrm{Ti}$ oxide.

Laser ablation traverses were carried out across the vesicles and into the groundmass (Fig. 7A). A comparison of peaks in LA-ICP-MS traverses gives qualitative information on the trace element content of mineral phases. In both vesicles and groundmass, peaks in trace elements (REE, $\mathrm{Y}, \mathrm{U}, \mathrm{Th}, \mathrm{Nb}, \mathrm{Zr}, \mathrm{W}$ and $\mathrm{Pb}$ ) commonly occur together with peaks in Ti and Ca (related to titanite), whereas $P$ (phosphates) appears to be less correlated. However, the largest peaks in REE, $\pm \mathrm{Y} \pm \mathrm{U}$, are related to the presence of fine grained REE-fluoro-carbonate. Lead, despite some correlation with Ti-Ca peaks (titanite), is less sensitive to variations in other elements and is mainly concentrated within the vesicles, irrespective of the mineral phase.

Vesicles are enriched in all the analysed trace elements, including REE (especially LREE and MREE), HFSE and transition elements ( $\mathrm{Cu}$,
$\mathrm{Zn}$, Mo, and $\mathrm{W}$ ), as well as $\mathrm{Ca}$ and Fe, compared to both the surrounding groundmass and whole rock (Fig. 7C, D). The highest degrees of enrichment between vesicles and groundmass were measured for $\mathrm{Pb}, \mathrm{Zn}, \mathrm{Cu}$ and LREE. Primitive mantle-normalised diagrams show generally similar patterns for vesicle filling and groundmass, with LREE enriched in comparison with HREE and negative peaks for $\mathrm{P}$ and Ti. However, the vesicles exhibit a more fractionated trend (average $\mathrm{La} / \mathrm{Yb}$ groundmass $<$ average $\mathrm{La} / \mathrm{Yb}$ vesicle; Fig. 7C).

Concentric zones of minerals in the groundmass around vesicles are confirmed by major element $(\mathrm{Si}, \mathrm{Al}, \mathrm{Ti}$, and $\mathrm{Fe}$ ) variations in $\mathrm{LA}-$ ICP-MS profiles. However, although a symmetrical decrease of trace element concentrations towards the vesicles was locally found, there seems to be no systematic distribution according to concentric zones.

\section{Discussion}

\subsection{The role of accessory minerals in the fractionation of trace elements}

Accessory minerals (fluorite, zircon, REE-fluoro-carbonate, Ti oxide, titanite and, to a lesser extent, apatite, monazite and allanite) are the main trace element-bearing phases. Some of these crystallised early (they occur as inclusions in major minerals) and played a role in the fractionation of trace elements in the melt. The evolution trends shown by trace elements are in agreement with the modal mineralogy and the observed textures. The sharp decrease of $\mathrm{P}$ and $\mathrm{Zr}$, occurring between 60 and 65 wt.\% silica and above 70 wt.\% silica, respectively, reflects the crystallisation of apatite and zircon and their inclusion relationship. Crystallisation of zircon, apatite and minor monazite may have also partially reduced the concentration of REE in the melt, and are consistent with the weakly decreasing trends observed (Fig. 3). Continuously increasing trends shown by other trace elements (e.g. $\mathrm{Nb}, \mathrm{Th}, \mathrm{Ta}$ ) indicate that these elements behaved as incompatible in the magma. 
Table 2

Whole rock major and trace element analyses.

\begin{tabular}{|c|c|c|c|c|c|c|}
\hline Sample & Det. & GH34 & GH67B & GH15 & GH70 & GH44 \\
\hline Locality & & Kokatha & Lake Everard & Lake Everard & Lake Everard & Kokatha \\
\hline Unit & & RD & BR & MDS & MDS & MGD \\
\hline $\mathrm{SiO} 2$ & & 71.65 & 79.66 & 75.60 & 75.16 & 76.44 \\
\hline $\mathrm{Al} 2 \mathrm{O} 3$ & & 13.87 & 9.99 & 11.88 & 12.19 & 12.66 \\
\hline $\mathrm{Fe} 2 \mathrm{O} 3$ & & 2.98 & 0.19 & 1.56 & 2.03 & 0.81 \\
\hline $\mathrm{MnO}$ & & 0.03 & 0.01 & 0.06 & 0.01 & 0.02 \\
\hline $\mathrm{MgO}$ & & 0.21 & 0.36 & 0.44 & 0.34 & 0.16 \\
\hline $\mathrm{CaO}$ & & 0.55 & 0.31 & 0.69 & 0.14 & 0.42 \\
\hline $\mathrm{Na} 2 \mathrm{O}$ & & 3.84 & 1.06 & 2.54 & 2.93 & 3.95 \\
\hline $\mathrm{K} 2 \mathrm{O}$ & & 5.73 & 7.50 & 5.95 & 5.63 & 4.71 \\
\hline P2O5 & & 0.06 & 0.02 & 0.02 & 0.05 & 0.03 \\
\hline S & & $<0.01$ & 0.01 & $<0.01$ & 0.01 & 0.01 \\
\hline LOI & & 0.36 & 0.94 & 1.37 & 1.00 & 0.71 \\
\hline Total & & 100.06 & 100.12 & 100.34 & 99.90 & 99.98 \\
\hline $\mathrm{Li}$ & 0.02 & 4.1 & 5.1 & 13.0 & 7.6 & 30.0 \\
\hline $\mathrm{Be}$ & 0.01 & 3.13 & 1.59 & 4.35 & 3.64 & 6.26 \\
\hline Sc & 0.04 & 6.2 & 2.2 & 3.4 & 4.1 & 2.0 \\
\hline $\mathrm{Ti}$ & 1.2 & 2681 & 516 & 986 & 1509 & 264 \\
\hline V & 0.01 & 4 & 3 & 2 & 9 & 8 \\
\hline $\mathrm{Cr}$ & 0.15 & 2 & 2 & 2 & 3 & 2 \\
\hline Mn & 0.41 & 221 & 72 & 458 & 101 & 130 \\
\hline $\mathrm{Ni}$ & 0.05 & 3 & 3 & 5 & 5 & 9 \\
\hline $\mathrm{Cu}$ & 0.12 & 3 & 2 & 2 & 2 & 1 \\
\hline $\mathrm{Zn}$ & 0.25 & 55 & 4 & 37 & 28 & 8 \\
\hline $\mathrm{Ga}$ & 0.03 & 19.7 & 4.4 & 15.3 & 14.9 & 24.6 \\
\hline As & 5 & $<5$ & $<5$ & $<5$ & $<5$ & $<5$ \\
\hline $\mathrm{Rb}$ & 0.04 & 177.8 & 291.9 & 312.1 & 271.6 & 798.1 \\
\hline $\mathrm{Sr}$ & 0.21 & 134.1 & 19.2 & 27.3 & 77.5 & 15.7 \\
\hline Y & 0.01 & 35.2 & 17.5 & 60.4 & 44.1 & 101.9 \\
\hline $\mathrm{Zr}$ & 0.04 & 321 & 95 & 231 & 233 & 147 \\
\hline $\mathrm{Nb}$ & 0 & 18 & 17 & 22 & 20 & 43 \\
\hline Mo & 0.02 & 1.48 & 0.34 & 1.11 & 0.46 & 0.24 \\
\hline $\mathrm{Ag}$ & 0.01 & 0.09 & 0.03 & 0.04 & 0.05 & 0.05 \\
\hline $\mathrm{Cd}$ & 0.02 & $<0.23$ & $<0.23$ & $<0.23$ & $<0.23$ & $<0.23$ \\
\hline Sn & 0.01 & 3.05 & 1.55 & 7.21 & 4.19 & 10.65 \\
\hline $\mathrm{Sb}$ & 0.05 & 0.12 & 0.14 & 0.44 & 0.11 & 0.24 \\
\hline $\mathrm{Te}$ & 0.09 & $<0.37$ & $<0.37$ & $<0.37$ & $<0.37$ & $<0.37$ \\
\hline Cs & 0 & 1.61 & 2.19 & 3.47 & 2.38 & 7.33 \\
\hline Ва & 0.29 & 1871 & 193 & 175 & 983 & 181 \\
\hline La & 0 & 63.8 & 16.4 & 112.0 & 79.9 & 34.2 \\
\hline $\mathrm{Ce}$ & 0.01 & 136.5 & 38.1 & 202.5 & 164.7 & 81.1 \\
\hline $\operatorname{Pr}$ & 0 & 16.53 & 3.82 & 23.62 & 17.63 & 10.18 \\
\hline $\mathrm{Nd}$ & 0.01 & 62.4 & 12.6 & 80.0 & 58.8 & 36.9 \\
\hline $\mathrm{Sm}$ & 0.01 & 11.07 & 2.54 & 13.70 & 9.89 & 10.20 \\
\hline $\mathrm{Eu}$ & 0 & 2.49 & 0.23 & 0.33 & 0.87 & 0.05 \\
\hline Gd & 0.01 & 8.95 & 2.59 & 10.96 & 8.09 & 11.11 \\
\hline $\mathrm{Tb}$ & 0 & 1.33 & 0.46 & 1.73 & 1.33 & 2.42 \\
\hline Dy & 0 & 7.12 & 2.70 & 10.14 & 7.80 & 16.41 \\
\hline Ho & 0 & 1.32 & 0.54 & 2.05 & 1.56 & 3.52 \\
\hline $\mathrm{Er}$ & 0 & 3.70 & 1.69 & 6.21 & 4.90 & 11.99 \\
\hline $\operatorname{Tm}$ & 0 & 0.52 & 0.26 & 0.94 & 0.76 & 2.05 \\
\hline $\mathrm{Yb}$ & 0 & 3.29 & 1.77 & 5.97 & 5.05 & 14.09 \\
\hline $\mathrm{Lu}$ & 0 & 0.51 & 0.28 & 0.91 & 0.78 & 2.12 \\
\hline $\mathrm{Hf}$ & 0 & 8.75 & 3.88 & 8.21 & 7.59 & 9.95 \\
\hline Тa & 0 & 1.62 & 1.75 & 2.50 & 2.35 & 7.93 \\
\hline $\mathrm{Tl}$ & 0.01 & 0.95 & 1.60 & 1.43 & 1.25 & 2.87 \\
\hline $\mathrm{Pb}$ & 0.16 & 34 & 6 & 7 & 8 & 40 \\
\hline $\mathrm{Bi}$ & 0.01 & 0.17 & 0.07 & 0.06 & 0.09 & 0.06 \\
\hline Th & 0 & 18.7 & 16.4 & 47.1 & 45.7 & 48.7 \\
\hline $\mathrm{U}$ & 0 & 0.76 & 1.38 & 9.17 & 2.47 & 8.25 \\
\hline
\end{tabular}

Major elements (XRF) as wt.\%, trace elements (ICP-MS) as ppm. RD: Rhyolite-dacite (Mi2), MD: Mangaroongah Dacite, BR: Baldry Rhyolite, MDS: Moonamby Dyke Suite, MGD: Microgranite Dyke.

\subsection{Late-stage crystallisation of accessory minerals}

The fact that trace element-bearing accessory minerals mostly occupy interstitial positions in the groundmass, infill cavities and occur in spaces between major phases (Figs. 4-6), implies a late crystallisation (Fig. 8). As mentioned, zircon and apatite occur as both early-formed inclusions in the major minerals, and as late-formed crystals in micromiaroles (Fig. 5B). Other accessory phases (anatase, titanite, fluorite, REE-F-carbonate, allanite and baryte) only occur in vesicles, micromiaroles and lithophysae (Figs. 4-6) or in an interstitial position in the groundmass, implying a late origin (Fig. 8).

REE-fluoro-carbonate (synchysite-(Ce)?) is the main trace element-bearing phase, having high concentrations of REE, Y, U, \pm Th. Total REE in REE-F-carbonate are three orders of magnitude higher than the whole rock content (semi-quantitative electron microprobe analysis). Normalised values show a light REE-enriched composition. Given such high concentrations, less than $0.1 \mathrm{wt} . \%$ of this mineral could be responsible for the whole rock REE content.

The formation of REE-fluoro-carbonates in felsic igneous rocks has been interpreted as a result of: (1) post-magmatic high-temperature alteration of accessory phases such as allanite, monazite, apatite and zircon, and remobilisation of REE by means of $\mathrm{F}$ - and $\mathrm{CO}_{2}$-rich fluids (Bea, 1996; Förster, 2001). (2) Crystallisation from a vapour, as suggested by Gilbert and Williams-Jones (2008), who reported the presence of REE-F-carbonate in fumarolic encrustations in a carbonatitic lava of Lengai volcano, Tanzania. (3) Crystallisation from silicate magma. Chabiron et al. (2001) reported the presence of parisite (Ca $\left.(\mathrm{Ce}, \mathrm{La})_{2} \mathrm{~F}_{2}\left(\mathrm{CO}_{3}\right)_{2}\right)$ as daughter crystals in melt inclusions from the rhyolites of the Streltsovka caldera (Russia).

In the rocks described here, none of these hypotheses seems applicable. Firstly, there is no evidence of alteration of magmatic accessory minerals. Therefore, an origin of REE-F-carbonate by alteration of magmatic accessory phases and remobilisation of trace elements is not likely. Secondly, a fumarolic (subaerial) environment described by Gilbert and Williams-Jones (2008) does not fit the described samples. Furthermore, a magmatic origin is not supported by textures. Instead, the hypothesis of direct crystallisation from a late-stage magmatic fluid is preferred.

\subsection{Characteristics of the late-stage fluid}

Because no fluid inclusions were found in the accessory minerals in the studied samples, direct evidence of the phase from which these minerals were deposited is not preserved. However, inferences on its physico-chemical characteristics can be made on the basis of textures and compositions of the minerals present:

1) Volatile-rich composition, as indicated by the widespread occurrence of F-bearing minerals (fluorite, REE-F-carbonate, and Fapatite), $\mathrm{CO}_{2}$-bearing minerals (carbonate), hydrous minerals (epidote), and the local presence of phosphates (apatite), and sulfate (baryte).

2) Capacity to transport lithophile, "immobile" elements (REE, Y, and HFSE), indicated by the presence of accessory minerals containing these elements.

3) Low viscosity. A growth from a low-viscosity phase is indicated by textures described above (Figs. 4-6), with minerals growing in cavities proceeding from the walls inwards (euhedral crystals of quartz, layered silica, fluorite, Ti oxide and titanite).

The role of halogens ( $\mathrm{F}$ and $\mathrm{Cl}$ ) as complexing agents for REE, $\mathrm{Y}$ and HFSE has been mentioned earlier (e.g. Gieré, 1986; Webster et al., 1989; Keppler and Wyllie, 1990; 1991; Charoy and Raimbault, 1994; Pan and Fleet, 1996; Audétat et al., 2000; Webster et al., 2004; Schönenberger et al., 2008). A mobility of these elements is shown by both experimental studies and evidence from natural systems. Hydrothermal systems enriched in these elements occur in different geological environments and the enrichment can reach ore grades (e.g. Metz et al., 1985; Gieré, 1986; Oreskes and Einaudi, 1990; Gieré and Williams, 1992; Monecke et al., 2002; Rubatto and Hermann, 2003). Thermodynamic calculations (Wood, 1990a,b; Lee and Byrne, 1992) and experimental work (Webster et al., 1989; Bau, 1991; Bau and Möller, 1992; Haas et al., 1995) show that complexation of trace elements with ligands such as $\mathrm{F}^{-}$and $\mathrm{Cl}^{-}$, but also $\mathrm{OH}^{-}, \mathrm{CO}_{3}^{2-}, \mathrm{PO}_{4}^{3-}$, and $\mathrm{SO}_{4}^{2-}$ can significantly increase the solubility of these elements and is 

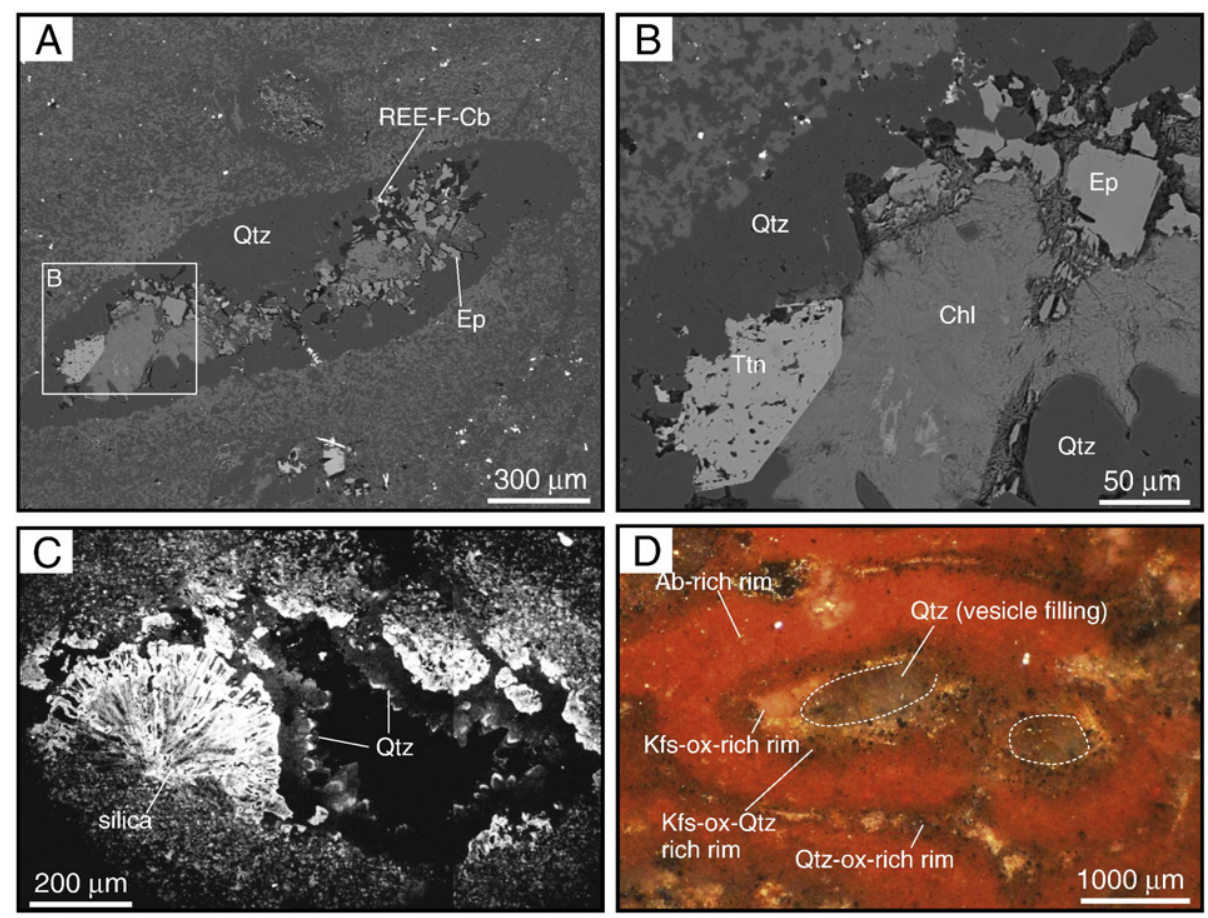

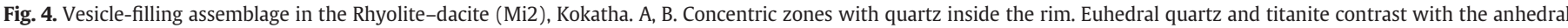

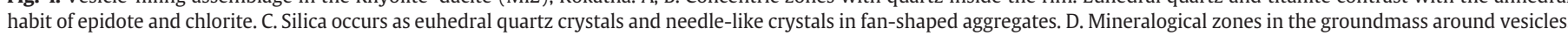

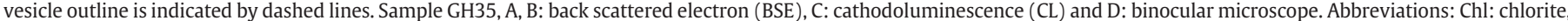
Ep: epidote, ox: oxide, REE-F-Cb: REE-fluoro-carbonate, Ttn: titanite.
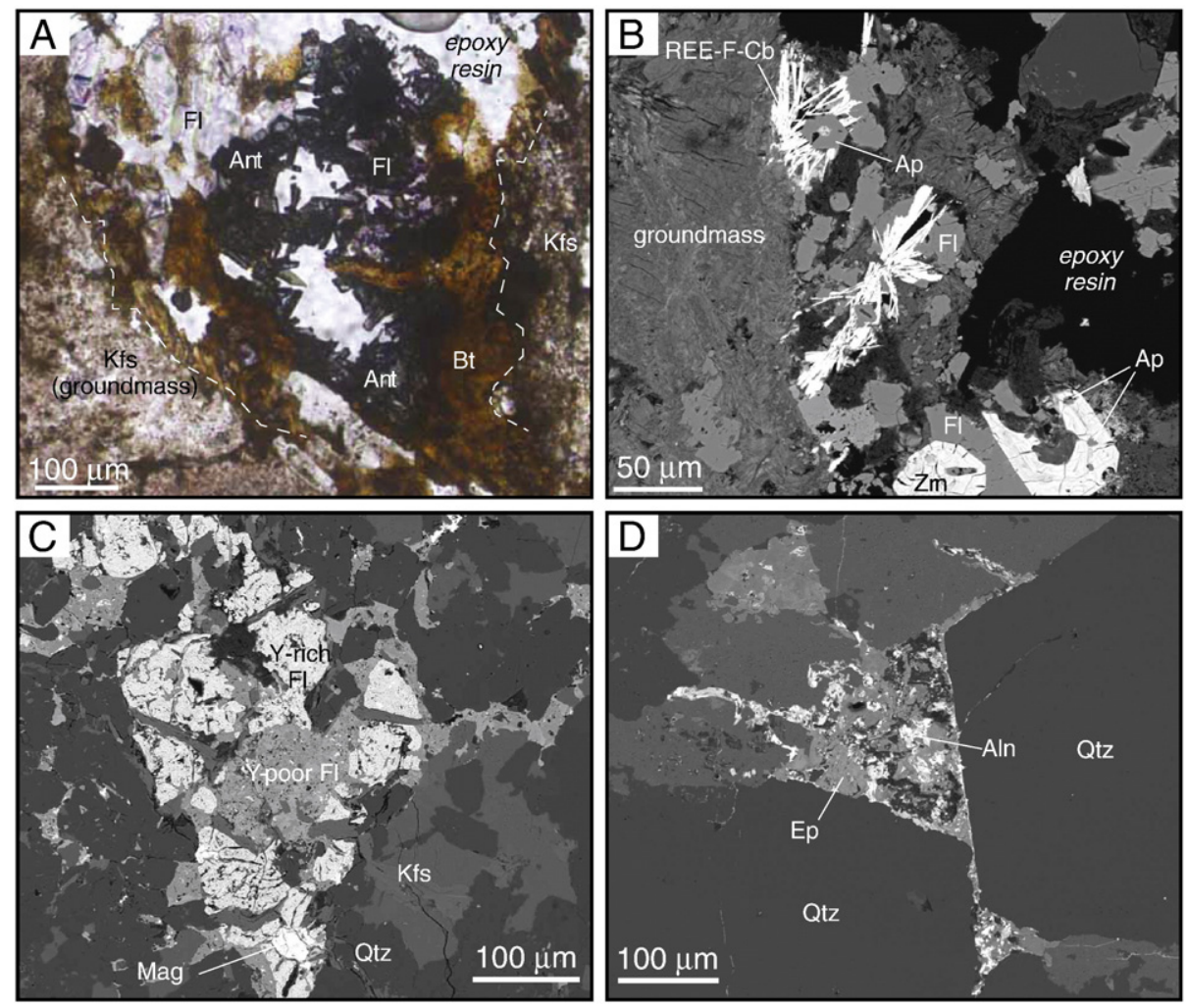

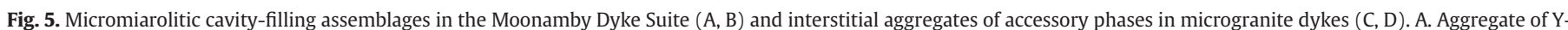

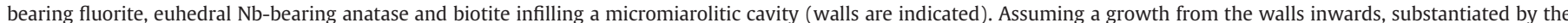

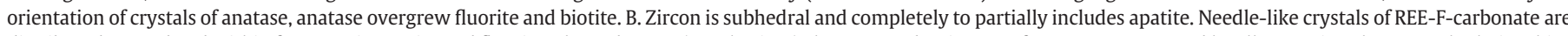

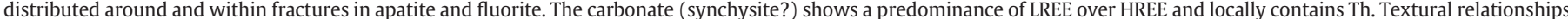

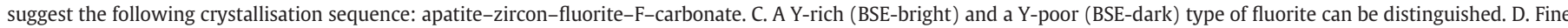

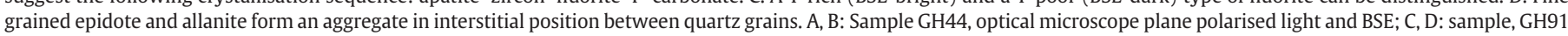
BSE. Abbreviations: Aln: allanite, Ant: anatase, Ap: apatite, Bt: biotite, Fl: fluorite, Mag: magnetite, Zrn: zircon. 

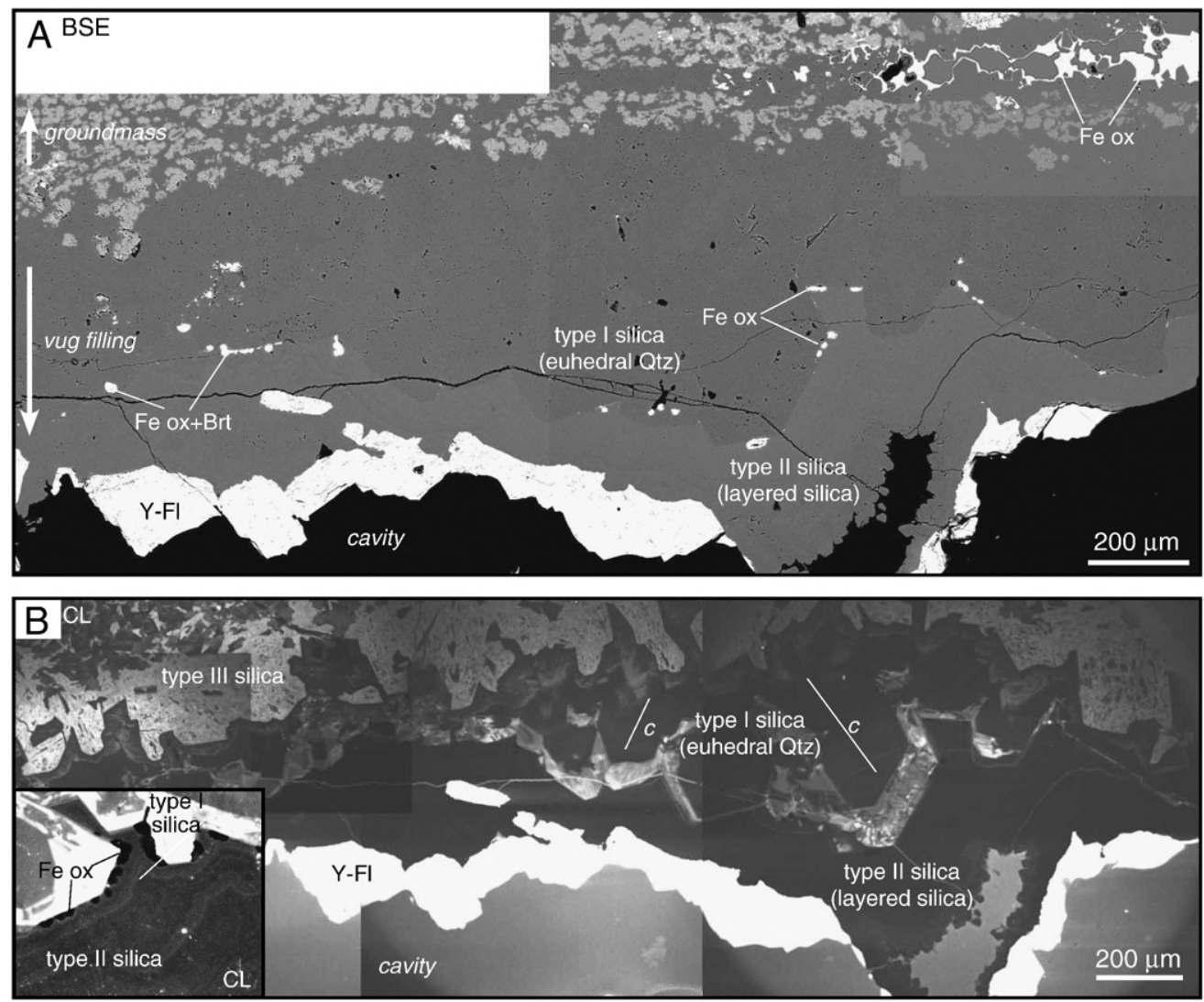

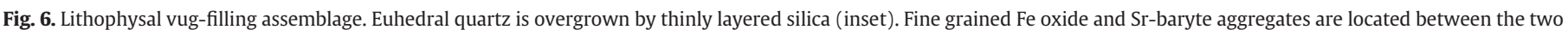

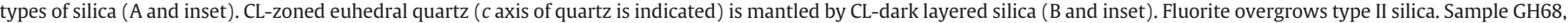
BSE (A) and CL (B). Abbreviations: Brt: baryte.

potentially important in natural systems. The stability of the complexes formed by these ligands with trace elements increases with temperature (Haas et al., 1995; Migdisov et al., 2009).

Fluorine was found to form complexes with REE, $U$ and Th, whereas it appears to have little or no influence on Cu and Sn (Keppler and Wyllie, 1990; 1991). Wendlant and Harrison (1979) found that REE partition significantly in favour of a $\mathrm{CO}_{2}$ vapour in equilibrium with a silicate liquid, and that the distribution coefficients are several orders of magnitude higher than for the silicate melt- $\mathrm{H}_{2} \mathrm{O}$ vapour equilibrium (Mysen, 1979). Experimental work by Keppler and Wyllie (1991) indicates that $\mathrm{CO}_{2}$ and $\mathrm{Cl}$ form complexes with $\mathrm{U}$, but not with Th. Copper and tin are essentially non soluble in pure water, even at high temperature $\left(750{ }^{\circ} \mathrm{C}\right)$, and their fluid/melt distribution is enhanced by $\mathrm{Cl}$, but not by $\mathrm{F}$ (Keppler and Wyllie, 1991). Solubility of Mo and $\mathrm{W}$, on the contrary, is pH-sensitive. These elements ( $\mathrm{W}$ and Mo) are more soluble in $\mathrm{H}_{2} \mathrm{O}$ fluids, and become less soluble if $\mathrm{HF}$ and $\mathrm{HCl}$ are added, as a consequence of the decrease in $\mathrm{pH}$ of the fluid (Keppler and Wyllie, 1991). In nature, a high and variable degree of enrichment in REE and HFSE (Th, U, and Nb), other than Sr, F and P, of carbonatitic melts and other $\mathrm{CO}_{2}$-rich melts is well known (Lentz, 1999). Furthermore, Pili et al. (2002) showed evidence for a mobility of trace elements (including REE, Ta, $\mathrm{Nb}$ and $\mathrm{Y}$ ) during brittle deformation of carbonates, thus proving that $\mathrm{CO}_{2}-\mathrm{H}_{2} \mathrm{O}$ fluids can mobilise these elements, even at low temperatures. Fluorine and $\mathrm{CO}_{2}$ have been invoked as complexing agents in the formation of REE-UTh-rich deposits (e.g. McLennan and Taylor, 1979; Simpson et al., 1979; Oreskes and Einaudi, 1990), consistently with fluoritecarbonate mineralisation commonly found in these deposits.

Because of the semi-volatile nature of fluorine, unlike water and $\mathrm{CO}_{2}$, the F-rich composition is another characteristic of this fluid that should be discussed. Fluorine is highly soluble in silicate liquids and is generally incompatible with most minerals and the fluid phase (Dolejš and Baker, 2007a). A fluid-silicate melt distribution coefficient $\mathrm{D}^{\mathrm{F}}$ ( $\mathrm{F}^{\text {fluid }} / \mathrm{F}^{\text {melt }}$ ) of $0.1-0.4$ has been measured for moderately high $\mathrm{F}$ concentrations ( $F \sim 1 \mathrm{wt} . \%$, London et al., 1988). However, the distribution coefficient depends on $\mathrm{F}$ abundance: high concentrations ( $\geq 7-8$ wt.\% $\mathrm{F}$ in the melt) will result in $\mathrm{D}^{\mathrm{F}}>1$ and in $\mathrm{F}$ preferentially partitioning into the fluid phase (Webster, 1990; Carroll and Webster, 1994). Such high concentrations are not common in nature. Values of $\mathrm{F}=2.9$ wt.\%, (Audétat et al., 2000), 3.2 wt.\% (Chabiron et al., 2001), 5 wt.\% (Webster et al., 2004), 6.4 wt.\% (Thomas et al., 2005) have been measured in melt inclusions and high whole rock $\mathrm{F}$ values (1.6 wt.\%) were reported in highly evolved topaz-bearing rhyolite (ongonite, Štemprok, 1991). In the lower GRV, we measured $\mathrm{F} \leq 1.3$ wt.\% in melt inclusions (unpublished data). However, considering the high $\mathrm{F}-\mathrm{Ca}$ ratios in melt inclusions $(\mathrm{F} / \mathrm{CaO}(\mathrm{wt} . \%) \leq 1.8)$, it becomes apparent that $\mathrm{F}$ content in some units cannot be accommodated by the observed paragenesis (F-apatite, fluorite and fluoro-carbonates), even if crystallisation of fluorite $(\mathrm{F} / \mathrm{CaO}=0.68)$ from the magma is admitted. Therefore, protracted crystallisation would lead to high concentrations of $\mathrm{F}$ in the last fractions of residual melt. Such "excess F", unbuffered by crystallising phases, could have eventually exsolved in a F-rich fluid phase upon volatile saturation. Significant enrichments in $\mathrm{F}$ were as also reported in experiments on F-bearing haplogranitic systems (Dolejš and Baker, 2007b).

\subsection{Origin of the fluid}

Whole rock analyses indicate a moderate-high concentration of REE and HFSE in the magma and increasing trends with progressing fractionation (increasing $\mathrm{Si}$ ). Therefore, the magma itself is the most obvious source of REE and HFSE. Further, high concentrations of $\mathrm{F}$ in 


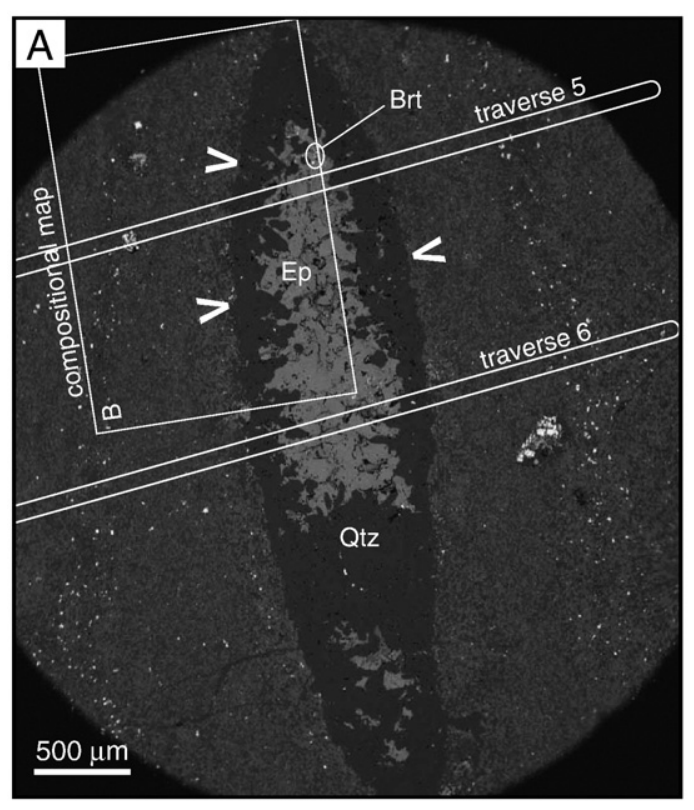

C

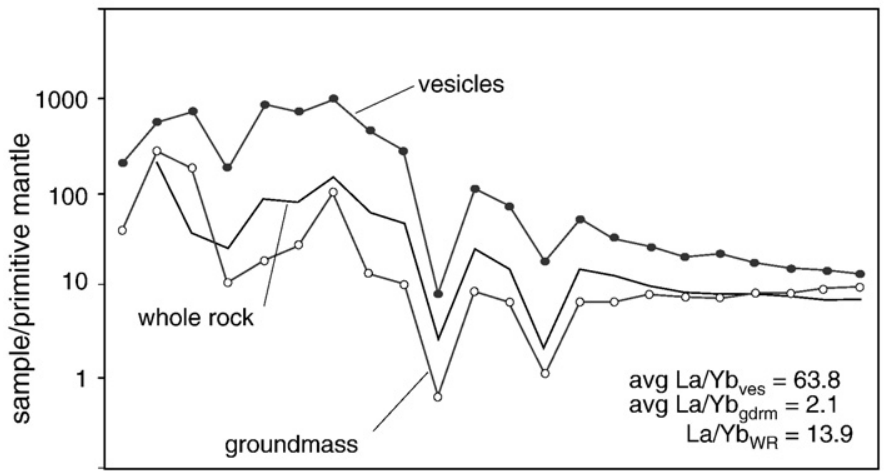

W Th U Nb La Ce Pb Pr Nd P SmEu Ti GdTb Dy Ho Y ErTm Yb Lu

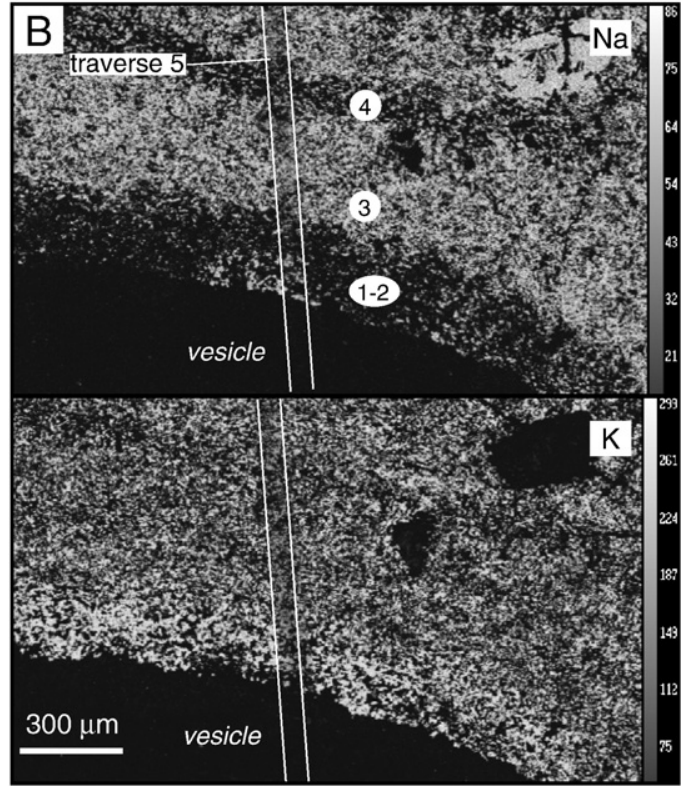

D

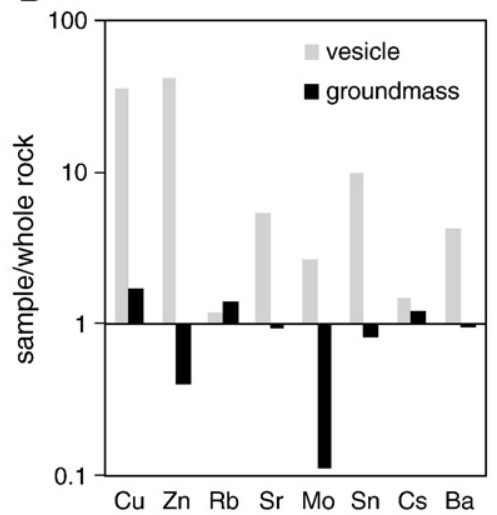

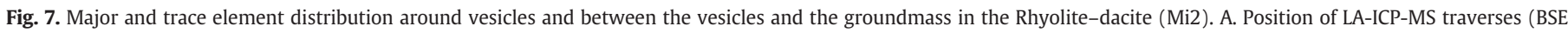

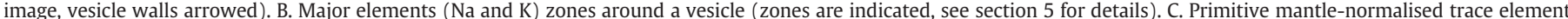

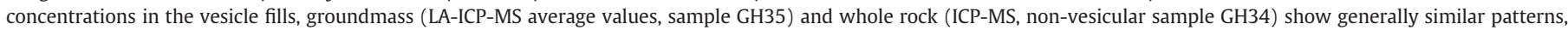
distinguished by a different La/Yb ratio. D. Whole rock (GH34)-normalised LILE and base metals. Normalising values after Sun and McDonough (1989).

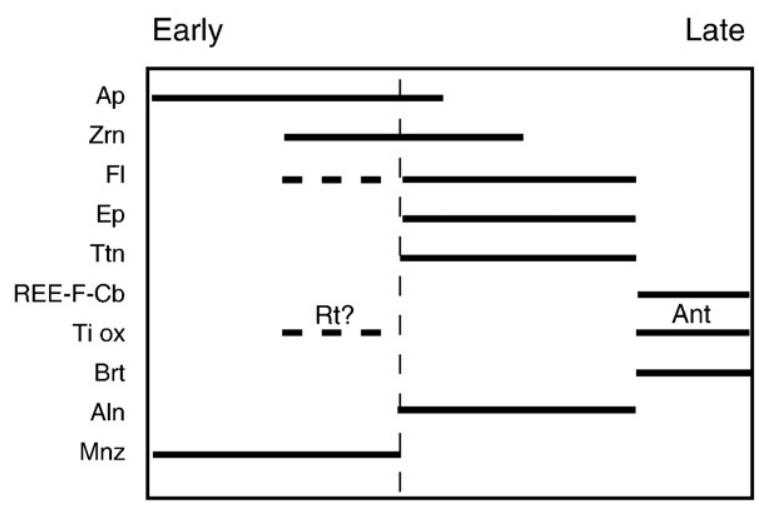

Fig. 8. Crystallisation sequence for the accessory minerals in the LGRV. Apatite and zircon are common in the groundmass of most samples and also occur in the micromiarolitic cavities. Fluorite occurs in interstitial position in the groundmass, and in vesicles, micromiarolitic cavities and lithophysae. Epidote occurs in vesicles and in interstitial aggregates in the groundmass of the Microgranite dyke, in association with allanite. Titanite is present in the vesicles in the Rhyolite-dacite (Mi2). REE-F-carbonate is common in micromiaroles and vesicles, and as late-formed crystals in the groundmass. Titanium oxide (anatase) occurs in the micromiaroles as a late-crystallising phase overgrowing fluorite. Titanium oxide (rutile?) also occurs in the groundmass of all the units. Baryte occurs in minor amounts in the vesicles and in the lithophysae. Monazite occurs in minor amounts as inclusions in the major phases of the Microgranite dykes. quartz-hosted melt inclusions ( $\mathrm{F} \leq 1.3 \mathrm{wt} . \%, \mathrm{Cl} \leq 0.2 \mathrm{wt} . \%$; unpublished data) provide a likely origin for $\mathrm{F}$.

However, an outstanding question is whether the fluid had a magmatic (or primary) origin or a much later, secondary origin. In the second hypothesis, a hot hydrothermal fluid, unrelated to the magma, could have leached the trace elements from the host rocks. We favour a magmatic origin, based on geochemical and micro-structural evidence. A first criterion to distinguish between these two hypotheses is geochemical. Primitive mantle-normalised trace element plots show close similarities between vesicle fillings, groundmass around vesicles and non-vesicular whole rock composition (Fig. 7C). The main difference lies in the steepness of the normalised trends, with patterns for the vesicle-filling minerals and the surrounding groundmass distributed symmetrically with respect to the non-vesicular samples (Fig 7C).

The increase in $\mathrm{La} / \mathrm{Yb}$ ratio of vesicles can be explained by the fractionation of modal minerals (quartz, feldspar, Fe-Ti oxide, zircon and apatite) and the preference of feldspar and zircon for HREE over LREE (e.g. Hinton and Upton, 2001). A slightly higher Rb concentration and lower $\mathrm{Sr}$ and $\mathrm{Ba}$ in the groundmass (Fig. 7D) is also consistent with fractionation of alkali-feldspar in the groundmass. A second criterion to distinguish between a magmatic and a secondary origin of the fluid is based on micro-structural evidence. A secondary fluid 
would either flow along cracks, depositing veins, or diffuse pervasively the rock. As shown, no evidence of a hydrothermal system or veins at any scale, and no significant alteration were found in the rocks, apart from a moderate sericitisation of feldspar. Furthermore, as mentioned, alteration of magmatic accessory phases would be needed to remobilise REE and HFSE (e.g. Förster, 2001), but this was not found.

\subsection{Formation of vesicles}

We propose a three-stage model for the formation of the vesicles that can also be applied to micromiaroles and lithophysae. This model is based on the following considerations: 1. Vesicle fillings and groundmass show similar trace element patterns, pointing to a common origin. Differences include a higher La/Yb ratio, (Fig. 7C) in the vesicles, compatible with the crystallisation of modal minerals in the groundmass and the formation of a highly fractionated residual melt. 2. The vesicles are not interconnected by veinlets or visible cracks, so that a late (secondary) ingress of fluid seems unlikely. 3 . The concentric zoning of major elements, but not trace elements, in the groundmass around the vesicles (Fig. 4D) suggests a contemporaneous formation of the zoning and the vesicles. We hypothesise that, during the formation of vesicles, a chemical zonation was created in the melt by a boundary layer effect (selective uptake of elements by the exsolving phase). During subsequent rapid crystallisation, this zonation was translated into an uneven mineral distribution (Figs. 3D, 7B), as crystals of quartz, feldspar and oxides formed according to the local availability of elements. Trace elements, incompatible with respect to the crystallising phases, were concentrated in the interstitial residual liquid. 4. Zonation of minerals within vesicles (Fig. 4) indicates that quartz crystallised first and then the other minerals at the centre.

The first stage of the model is the exsolution of a fluid from the silicate liquid resulting in the formation of vesicles (Fig. 9-I). Quartz adjacent to the vesicle walls may have crystallised from this fluid. In a second stage, crystallisation of major minerals in the groundmass around the vesicles forms a residual liquid containing high concentrations of volatile and trace elements. A fluid phase exsolves from such an "enriched" residual melt (Fig. 9-II). Alternatively, a very evolved and volatile-rich residual melt could meet the required characteristics (e.g. Keppler and Wyllie, 1991). This fluid moves through a framework of fine grained quartz and feldspars in an already mostly crystallised rock and concentrates within the vesicles previously formed (open system behaviour of the vesicles). The core assemblage of minerals, rich in F, REE, Y and HFSE, crystallises from such a fluid (Fig. 9-III).

Smith (1967), Bloomer (1994) and De Hoog and van Bergen (2000) reported the presence of vesicle fillings and veins enriched in incompatible trace elements in volcanic rocks from different environments. They interpreted these aggregates, termed segregations by Smith (1967), to have crystallised from a residual liquid. According to the mechanism proposed by Smith (1967) and adopted by Bloomer (1994), a residual liquid was mobilised and injected into the vesicles by fluid overpressure developed during crystallisation of the groundmass.

7.6. Implications on the transport of REE, $Y$ and HFSE in the late magmatic stage

We have shown that the GRV magmas produced volatile-rich, Fbearing phase at a late stage of evolution. A distinctive assemblage of REE-, HFSE- and F-bearing minerals (including REE-F-carbonate, REE phosphates and fluorite) crystallised from this phase where it filled vesicles, micromiaroles and lithophysal vugs. A similar mineral association and the same high REE and F abundances are characteristic of the U-bearing iron oxide copper-gold deposits in the Olympic Dam province, which is hosted in associated rocks of the Hiltaba Suite Granite (Oreskes and Einaudi, 1990; Skirrow et al., 2007). This similarity could imply a genetic link, largely overlooked in the literature, between GRV-HS magmas and the mineralising hydrothermal system at Olympic Dam.

\section{Conclusions}

Accessory mineral assemblages contained in micromiaroles, vesicles and lithophysal vugs or occupying interstitial positions in the GRV include significant amounts of REE (lanthanides, U, and Th), $\mathrm{Y}, \operatorname{HFSE}(\mathrm{Ti}, \mathrm{Zr}$, and $\mathrm{Nb})$ and transition metals $(\mathrm{Cu}, \mathrm{Zn}, \mathrm{Mo}$, and $\mathrm{W})$. These elements are mainly concentrated in REE-fluoro-carbonate, zircon, niobian Ti oxide, fluorite, titanite and, to a lesser extent, apatite and allanite. Textures and mineral associations indicate that these accessory minerals formed at a late magmatic stage, rather than in super-solidus conditions and that they crystallised from a volatile ( $\mathrm{F}$, $\mathrm{H}_{2} \mathrm{O}, \mathrm{CO}_{2}, \pm \mathrm{P}$, and $\pm \mathrm{S}$ )-rich low-viscosity (fluid) phase. It is inferred that fluorine played the dual role of promoting incompatible behaviour and concentration of lithophile trace elements in the residual magmatic liquid and, together with other complexing agents
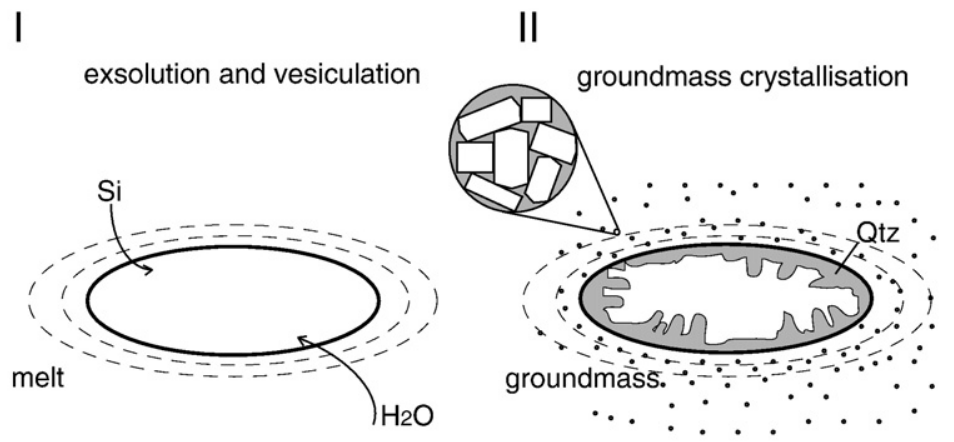

Exsolution of a fluid phase and vesiculation.
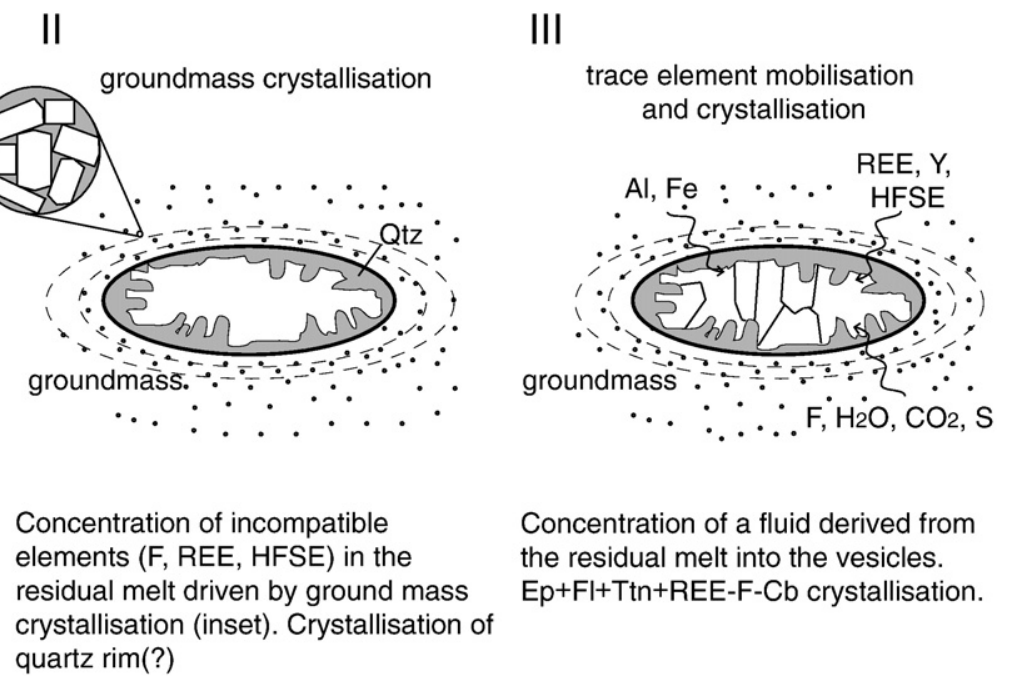
$\left(\mathrm{CO}_{2}, \mathrm{OH}\right.$, and $\left.\mathrm{P}\right)$, allowing the transport of the same "immobile" elements in a fluid in the late magmatic stage.

Experimental data (London et al., 1988; Webster, 1990; Keppler and Wyllie, 1991) and melt inclusion studies in pegmatites (Thomas et al., 2000; 2009) have shown that silicate melts can contain very high amounts of water. Such a high solubility of silicate and volatile component allows the existence of fluid phases with intermediate properties between an aqueous fluid and a silicate melt in terms of both composition and physical characteristics. The presence of REEand HFSE-bearing minerals (e.g. zircon, xenotime, fluorite, fluorocarbonate) described by Thomas et al. (2009) in pegmatites, implies that this kind of fluids are able to transport significant amounts of lithophile elements. Such a volatile- and silicate-rich fluid phase could account for the textural, mineralogical and compositional data described here.

\section{Acknowledgements}

The research was funded by ARC-CODES grants to the authors. Dr. I. Chambefort is thanked for reviewing an early version of manuscript and for insightful discussions. Comments of two anonymous reviewers significantly improved the manuscript. Field and logistical support were provided by the Primary Industry of South Australia (PIRSA). We also acknowledge Dr. Karsten Gömann, Simon Stephens, Philip Robinson, Katie McGoldrick (University of Tasmania) for analytical assistance.

\section{References}

Allen, S.R., McPhie, J., 2002. The Eucarro Rhyolite, Gawler Range Volcanics, South Australia: a $>675 \mathrm{~km}^{3}$, compositionally zoned lava of Mesoproterozoic age. Geological Society of America Bulletin 114 (12), 1592-1609.

Allen, S.R., McPhie, J., Ferris, G., Simpson, C., 2008. Evolution and architecture of a large felsic Igneous Province in western Laurentia: the $1.6 \mathrm{Ga}$ Gawler Range Volcanics, South Australia. Journal of Volcanology and Geothermal Research 172, 132-147.

Audétat, A., Günther, D., Heinrich, C.A., 2000. Magmatic-hydrothermal evolution in a fractionating granite: a microchemical study of the Sn-W-F-mineralized Mole Granite (Australia). Geochimica et Cosmochimica Acta 64 (19), 3373-3393.

Bailey, J.C., 1977. Fluorine in granitic rocks and melts: a review. Chemical Geology 19, 1-42.

Bau, M., 1991. Rare earth element mobility during hydrothermal and metamorphic fluid-rock interaction and the significance of the oxidation state of europium. Chemical Geology 93, 219-230.

Bau, M., Möller, P., 1992. Rare earth element fractionation in metamorphogenic hydrothermal calcite, magnesite and siderite. Contributions to Mineralogy and Petrology 45, 231-246.

Bea, F., 1996. Residence of REE, Y, Th and $U$ in Granites and crustal protoliths: implications for the chemistry of crustal melts. Journal of Petrology 7 (3), 521-552.

Blissett, A.H., Creaser, R.A., Daly, S.J., Flint, R.B., Parker, A.J., 1993. Gawler Range Volcanics. In: Drexel, J.F., Preiss, W.V., Parker, A.J. (Eds.), The Geology of South Australia. : The Precambrian, Vol. 1. Geological Survey of South Australia, pp. 107-124.

Blissett, A.H., 1975. Rock units in the Gawler Range Volcanics, South Australia. Quarterly Geological Notes 55. Geological Survey of South Australia, pp. 2-14.

Bloomer, S.H., 1994. Origin of segregation vesicles in volcanic rocks from The Lau Basin, Leg 135. In: Hawkins, J., Parson, L., Allan, J., et al. (Eds.), Proceedings of the Ocean Drilling Program, scientific results, vol. 135, pp. 615-623.

Branch, C.D., 1978. Evolution of the middle Proterozoic Chandabooka Caldera, Gawler range acid volcano-plutonic province, South Australia. Journal of the Geological Society of Australia 25 (4), 199-216.

Candela, P.A., 1997. A review of shallow, ore-related granites: textures, volatiles, and ore metals. Journal of Petrology 38 (12), 1619-1633.

Candela, P.A., Blevin, P.L., 1995. Do some miarolitic granites preserve evidence of magmatic volatile phase permeability? Economic Geology 90, 2310-2316.

Carroll, M.R., Webster, J.D., 1994. Solubilities of sulfur, noble gases, nitrogen, chlorine, and fluorine in magmas. In: Carroll, M.R., Holloway, J.R. (Eds.), Reviews in Mineralogy 30. Washington DC, Mineralogical Society of America.

Cas, R.A.F., Wright, J.V., 1987. Volcanic Successions: Modern and Ancient. Allen and Unwin, London.

Chabiron, A., Alyoshin, A.P., Cuney, M., Deloule, E., Golubev, V.N., Velitchkin, V.I., Poty, B., 2001. Geochemistry of the rhyolitic magmas from the Streltsovka caldera (Transbaikalia, Russia): a melt inclusion study. Chemical Geology 175, 273-290.

Charoy, B.L., Raimbault, L., 1994. Zr-, Th-, and REE-rich biotite differentiates in the Atype granite pluton of Suzhou (Eastern China): the key role of fluorine. Journal of Petrology 35 (4), 919-962.

Cullers, R.L., Medaris, L.G., Haskin, L.A., 1973. Experimental studies of the distribution of rare earths as trace elements among silicate minerals and liquids and water. Geochimica et Cosmochimica Acta 37, 1499-1512.
De Hoog, J.C., van Bergen, M.J., 2000. Volatile-induced transport of HFSE, REE, Th and U in arc magmas: evidence from zirconolite-bearing vesicles in potassic lavas of Lewotolo volcano (Indonesia). Contributions to Mineralogy and Petrology 139, 485-502.

Dingwell, D.B., Christopher, I., Scarfe, M., Cronin, D.J., 1985. The effect of fluorine on viscosities in the system $\mathrm{Na}_{2} \mathrm{O}-\mathrm{Al}_{2} \mathrm{O}_{3}-\mathrm{SiO}_{2}$ : implications for phonolites, trachytes and rhyolites. American Mineralogist 70, 80-87.

Dolejš, D., Baker, D.R., 2007a. Liquidus equilibria in the system $\mathrm{K}_{2} \mathrm{O}-\mathrm{Na}_{2} \mathrm{O}-\mathrm{Al}_{2} \mathrm{O}_{3}-\mathrm{SiO}_{2}-$ $\mathrm{F}_{2} \mathrm{O}_{1}-\mathrm{H}_{2} \mathrm{O}$ to100MPa: I. Silicate-fluoride liquid immiscibility in anhydrous systems. Journal of Petrology 48 (4), 785-806.

Dolejš, D., Baker, D.R., 2007b. Liquidus equilibria in the system K2O-Na2O-Al2O3SiO2-F2O1-H2O to $100 \mathrm{MPa}$ : II. Differentiation paths of fluorosilicic magmas in hydrous systems. Journal of Petrology 48 (4), 807-828.

Fanning, C.M., Flint, R.B., Parker, A.J., Ludwig, K.R., Blissett, A.H., 1988. Refined Proterozoic evolution of the Gawler Craton, South Australia, through U-Pb zircon geochronology. Precambrian Research 40, 363-386.

Flint, R.B., 1993. Hiltaba Suite. In: Drexel, J.F., Preiss, W.V., Parker, A.J. (Eds.), The Geology of South Australia. : The Precambrian, vol. 1. Geological Survey of South Australia, pp. 127-131.

Förster, H.J., 2001. Synchysite-(Y)-synchysite-(Ce) solid solutions from Markersbach, Erzgebirge, Germany: REE and Th mobility during high-T alteration of highly fractionated aluminous A-type granites. Mineralogy and Petrology 72, 259-280.

Gieré, P., 1986. Zirconolite, allanite and hoegbomite in a marble skarn from the Bergel contact aureole: implications for mobility of $\mathrm{Ti}, \mathrm{Zr}$ and REE. Contributions to Mineralogy and Petrology 93, 459-470.

Gieré, R., Williams, C.T., 1992. REE-bearing minerals in a Ti-rich vein from the Adamello contact aureole (Italy). Contributions to Mineralogy and Petrology 112, 83-100.

Gilbert, C.D., Williams-Jones, A.E., 2008. Vapour transport of rare earth elements (REE) in volcanic gas: Evidence from encrustations at Oldoinyo Lengai. Journal of Volcanology and Geothermal Research 176, 519-528.

Giles, C.W., 1977. Rock units in the Gawler Range Volcanics, Lake Everard area, South Australia. South Australia Geological Survey. Quaterly Geological Notes 61, 7-16.

Giles, C.W., 1988. Petrogenesis of the Proterozoic Gawler Range Volcanics, South Australia. Precambrian Research 40 (41), 407-427.

Giordano, D., Romano, C., Dingwell, D.B., Poe, D., Behrens, H., 2004. The combined effects of water and fluorine on the viscosity of silicic magmas. Geochimica et Cosmochimica Acta 68 (24), 5159-5168.

Haas, J.R., Shock, E.L., Sassani, D.C., 1995. Rare earth elements in hydrothermal systems: estimates of standard partial molal thermodynamic properties of aqueous complexes of the rare earth elements at high pressures and temperatures. Geochimica et Cosmochimica Acta 59, 4329-4350.

Hinton, R.W., Upton, B.G.J., 2001. The chemistry of zircon: variations within and between large crystals from syenite and alkali basalt xenoliths. Geochimica et Cosmochimica Acta 55, 3287-3302.

Hu, Z., Gao, S., 2008. Upper crustal abundances of trace elements: a revision and update. Chemical Geology 253, 205-221.

Keppler, H., 1993. Influence of fluorine on the enrichment of high field strength trace elements in granitic rocks. Contributions to Mineralogy and Petrology 114, 479-488.

Keppler, H., Wyllie, P.J., 1990. Role of fluids in transport and fractionation of uranium and thorium in magmatic processes. Nature $348,531-533$.

Keppler, H., Wyllie, P.J., 1991. Partitioning of Cu, Sn, Mo, W, U, and Th between melt and aqueous fluid in the systems haplogranite- $\mathrm{H} / \mathrm{O}-\mathrm{HCl}$ and haplogranite- $\mathrm{H}_{2} \mathrm{O}-\mathrm{HF}$. Contributions to Mineralogy and Petrology 109, 139-150.

Kile, D.E., Eberl, D., 1999. Crystal growth mechanisms in miarolitic cavities in the Lake George ring complex and vicinity, Colorado. American Mineralogist 84, 718-724.

Le Bas, M.J., Le Maitre, R.W., Streckeisen, A., Zanettin, B., 1986. A chemical classification of volcanic rocks based on the total alkali-silica diagram. Journal of Petrology 27 (3), 745-750.

Lee, J.H., Byrne, R.H., 1992. Examination of comparative rare earth element complexation behavior using linear free-energy relationships. Geochimica et Cosmochimica Acta 56, 1127-1137.

Lentz, D.R., 1999. Carbonatite genesis: a reexamination of the role of intrusion-related pneumatolytic skarn processes in limestone melting. Geology 27, 335-338.

Lesher, C.M., Gibson, H.L., Campbell, I.H., 1986. Composition-volume changes during hydrothermal alteration of andesite at Buttercup Hill, Noranda District, Quebec. Geochimica et Cosmochimica Acta 50, 2693-2705.

London, D., 1986. Formation of tourmaline-rich gem pockets in miarolitic pegmatites American Mineralogist 71, 396-405.

London, D., Hervig, R.L., Morgan, G.B., 1988. Melt-vapor solubilities and elemental partitioning in peraluminous granite-pegmatite systems: experimental results with Macusani glass at 200 Mpa. Contributions to Mineralogy and Petrology 99, 360-373.

Manning, D.A.C., 1981. The effect of fluorine on liquidus phase relationships in the system Qz-Ab-Or with excess water at $1 \mathrm{~kb}$. Contributions to Mineralogy and Petrology 76, 206-215.

McArthur, A.N., Cas, R.A.F., Orton, G.J., 1998. Distribution and significance of crystalline, perlitic and vesicular textures in the Ordovician Garth Tuff (Wales). Bulletin of Volcanology 60, 260-285.

McLennan, S.M., Taylor, S.R., 1979. Rare earth element mobility associated with uranium mineralisation. Nature 282, 247-249.

McPhie, J., Doyle, M., Allen, R., 1993. Volcanic Textures: a Guide to the Interpretation of Textures in Volcanic Rocks. University of Tasmania Centre for Ore Deposit and Exploration Studies, Hobart. 198 pp.

Metz, M.C., Brookins, D.G., Rosenberg, P.E., Zartman, R.E., 1985. Geology and geochemistry of the Snowbird deposit, Mineral county, Montana. Economic Geology 80, 394-409. 
Michard, A., Albarède, F., 1986. The REE contents of some hydrothermal fluids. Chemical Geology 55, 51-60.

Migdisov, A.A., Williams-Jones, A.E., Wagner, T., 2009. An experimental study of the solubility and speciation of the Rare Earth Elements (III) in fluoride- and chloridebearing aqueous solutions at temperatures up to $300 \mathrm{C}$. Geochimica et Cosmochimica Acta 73, 7087-7109.

Möller, P., Dulsky, P., Morteani, G., 2003. Partitioning of rare earth elements, yttrium, and some major elements among source rocks, liquid and vapor of LarderelloTravale Geothermal Field, Tuscany (Central Italy). Geochimica et Cosmochimica Acta 67 (2), 171-183.

Monecke, T., Kempe, U., Monecke, J., Sala, M., Wolf, D., 2002. Tetrad effect in rare earth element distribution patterns: a method of quantification with application to rock and mineral samples from granite-related rare metal deposits. Geochimica et Cosmochimica Acta 66, 1185-1196.

Mysen, B.O., 1979. Trace-element partitioning between garnet peridotite minerals and water-rich vapor: experimental data from 5 to 30 kbar. American Mineralogist 64, 274-287.

Oreskes, N., Einaudi, M.T., 1990. Origin of rare earth element-enriched hematite breccias at the Olympic Dam Cu-U-Au-Ag deposit, Roxby Downs, South Australia. Economic Geology 85, 1-28.

Pan, Y., Fleet, M.E., 1996. Rare earth element mobility during prograde granulite facies metamorphism: significance of fluorine. Contribution to Mineralogy and Petrology $123,251-262$.

Pili, E., Poitrasson, F., Gratier, J.-P., 2002. Carbon-oxygen isotope and trace element constraints on how fluid percolate faulted limestones from San Andreas Fault system: partitioning of fluid sources and pathways. Chemical Geology 190, 231-250.

Roedder, E., 1981. Natural occurrence and significance of fluids indicating high pressure and temperature. Physics and Chemistry of the Earth 13, 9-39.

Rubatto, D., Hermann, J., 2003. Zircon formation during fluid circulation in eclogites (Monviso, Western Alps): Implications for $\mathrm{Zr}$ and $\mathrm{Hf}$ budget in subduction zones. Geochimica et Cosmochimica Acta 67 (12), 2173-2187.

Schönenberger, J., Köhler, J., Markl, G., 2008. REE systematics of fluorides, calcite and siderite in peralkaline plutonic rocks from the Gardar Province, South Greenland. Chemical Geology 247, 16-35.

Simpson, P.R., Brown, G.C., Plant, J., Ostle, D., 1979. Uranium mineralization and granite magmatism in the British Isles. Philosophical Transactions. Royal Society of London A291, 385-412.

Skirrow, R.G., Bastrakov, E.N., Barovich, K., Fraser, G.L., Creaser, R.A., Fanning, C.M., Raymond, O.L., Davidson, G.J., 2007. Timing of iron oxide $\mathrm{Cu}-\mathrm{Au}-(\mathrm{U})$ hydrothermal activity and Nd isotope constraints on metal sources in the Gawler Craton, South Australia. Economic Geology 102, 1441-1470.

Smith, R.E., 1967. Segregation vesicles in basaltic lava. American Journal of Science 265, 696-713.

Štemprok, M., 1991. Ongonite from Ongon Khairkhan, Mongolia. Mineralogy and Petrology 43, 255-273.

Sun, S.S., McDonough, W.F., 1989. Chemical and isotopic systematics of oceanic basalts: implication for mantle composition and processes. In: Sanders, A.D., Norry, M.J. (Eds.), Magmatism in the Ocean Basins. Geological Society Special Publication, London, pp. 313-345.

Thomas, R., Davidson, P., Rhede, D., Leh, M., 2009. The miarolitic pegmatites from the Konigshain: a contribution to understanding the genesis of pegmatites. Contributions to Mineralogy and Petrology 157, 505-523.

Thomas, R., Förster, H.J., Rickers, K., Webster, J.D., 2005. Formation of extremely F-rich hydrous melt fractions and hydrothermal fluids during differentiation of highly evolved tin-granite magmas: a melt/fluid-inclusion study. Contributions to Mineralogy and Petrology 148, 582-601.

Thomas, R., Webster, J.D., Heinrich, W., 2000. Melt inclusions in pegmatite quartz: complete miscibility between silicate melts and hydrous fluids at low pressure. Contributions to Mineralogy and Petrology 139, 394-401.

Webster, J., Thomas, R., Förster, H.J., Seltmann, R., Tappen, C., 2004. Geochemical evolution of halogen-enriched granite magmas and mineralizing fluids of the Zinnwald tintungsten mining district, Erzgebirge, Germany. Mineralium Deposita 39, 452-472.

Webster, J.D., 1990. Partitioning of $\mathrm{F}$ between $\mathrm{H}_{2} \mathrm{O}$ and $\mathrm{CO}_{2}$ fluids and topaz rhyolite melt. Contributions to Mineralogy and Petrology 104, 424-438.

Webster, J.D., Holloway, J.R., Hervig, R.L., 1989. Partitioning of lithophile trace elements between $\mathrm{H}_{2} \mathrm{O}$ and $\mathrm{H}_{2} \mathrm{O}+\mathrm{CO}_{2}$ fluids and topaz rhyolite melt. Economic Geology 84, 116-134.

Wendlant, R.F., Harrison, W.J., 1979. Rare earth partitioning between immiscible carbonate and silicate liquids and $\mathrm{CO}_{2}$ vapor: results and implications for the formation of light rare earth-enriched rocks. Contributions to Mineralogy and Petrology 69, 409-419.

Wood, S.A., 1990a. The aqueous geochemistry of the rare-earth elements and yttrium 1. Review of available low-temperature data for inorganic complexes and the inorganic REE speciation of natural waters. Chemical Geology 82, 159-186.

Wood S.A. 1990b. The aqueous geochemistry of the rare-earth elements and yttrium 2. Theoretical predictions of speciation in hydrothermal solutions to $350{ }^{\circ} \mathrm{C}$ at saturation water vapor pressure. Chemical Geology 88, 99-125. 